\title{
Book Review: Where Are We Now? Michael Ignatieff's The Ordinary Virtues: Moral Order in a Divided World
}

\author{
Malcolm MacLaren*
}

(Received 18 May 2018; accepted 18 May 2018)

\begin{abstract}
The book that has most stimulated my life in the law over the past year is Michael Ignatieffs The Ordinary Virtues: Moral Order in a Divided World. ${ }^{1}$ I write "stimulated" rather than "inspired" because some of its claims are disorientating, others are disputable, and the most important are disconcerting. Despite, or rather due to, that provocation I find the book more engaging. The Ordinary Virtues is a self-described moral progress report amid globalization and as such is a work of sociology, anthropology, and philosophy. However, Ignatieffs report implicates many important topical issues of international and constitutional law. It should, I believe, inform the thinking of legal scholars on global ethics and public policy today.
\end{abstract}

Keywords: Human rights; global ethics; public policy

\section{A. Background on the Author and Book}

Ignatieff is head of the Central European University. He has held posts at other universities worldwide, most notably the Carr Center for Human Rights Policy at Harvard. More generally, Ignatieff is a public intellectual, having long contributed to public affairs as a commentator and politician. ${ }^{2}$ He has been described as a "bellwether of liberal internationalism." 3 Notably, Ignatieff's writing shows how the aspirations of the 1990s and its widespread faith in human rights have given way to the less hopeful, "realistic" perspectives of the early 21 st century. The broad commitment to political liberalism and the agenda for freedom are being increasingly challenged. ${ }^{4}$

With this new book project, Ignatieff quit the seminar room, forsook the relative harmony of multicultural Manhattan, and undertook a three-year, four-continent tour to observe moral values in people's actions out in the field. The author sought to find out whether, as globalization brings us physically and virtually closer together, our values are also converging, especially regarding human rights. Ignatieff s tour took him to people and areas experienced in ethnic conflict, corruption, and poverty. Through histories, sketches, and interviews, he reports in The Ordinary Virtues on the moral progress of residents of little-known shantytowns as well as global cities.

\footnotetext{
${ }^{*}$ Malcolm MacLaren is a Privatdozent in the Faculty of Law at the University of Zurich.

'Michael IgnatiefF, The Ordinary Virtues: Moral Order in a Divided World (2017).

${ }^{2}$ Ignatieff has written other books on ethnic war, human rights as politics, nation-building, and political ethics in the age of terror. See Michael Ignatieff, CEU People, https://people.ceu.edu/michael_ignatieff (last visited Apr. 30, 2019).

${ }^{3}$ Samuel Moyn, Reviews, The Ordinary Virtues: Moral Order in a Divided World, HarVard UnIVERSITY Press, http://www. hup.harvard.edu/catalog.php?isbn=9780674976276 (last visited Apr. 30, 2019).

${ }^{4}$ Ignatieff laments that "[i]nstead of embracing the future, imagining radiant tomorrows, we now think of the future in the language of harm reduction, target hardening, and risk management." IGNATIEFF, supra note 1, at 143.
} 


\section{B. Summary of the Book's Claims}

Ignatieffs principal observation is that "human rights may be the language of states and liberal elites," but that "the moral language that resonates with most people is that of everyday virtues," i.e. of trust, tolerance, forgiveness, reconciliation, and resilience. ${ }^{5}$ No grand principles like the Universal Declaration of Human Rights of 1948 have drawn, or can draw, the world together. Instead, it is the so-called ordinary virtues, the collection of everyday habits and intuitions, that are the "moral operating system," ${ }^{\text {" }}$ guiding us amid competing ideas and demands.

The author elaborates on the meaning of his principal observation as regards psychology, conscience, and morality. In his fieldwork, Ignatieff found that the ordinary virtues are not "heroic and exceptional" but are "commonplace." They are not the outcome of abstract moral reasoning and general human obligations. They are "unreflexive and unthinking," 8 the demonstration of existing community-based solidarity.

Ignatieff also explains the epistemological significance of his principal observation. The ordinary virtues lack a shared narrative or a universalist application; theirs is a non-reciprocal, "contextual singularity." 9 Rather than in terms of the so-called veil of ignorance and the whole of humankind, people deal ethically in terms of concrete human relations with family and friends, caste and community. Their spatio-temporal situation is decisive. The moral language of most people is, he sums, anti-theoretical, non-ideological, and inconsistent. ${ }^{10}$

Most importantly, Ignatieff draws the following inferences from the prevalence of the ordinary virtues for the conception of international relations and domestic politics.

- Whatever references may be made to the global-for example in jihadist rhetoricIgnatieff argues that politics remains rooted in the local or "parochial."

- The book's subjects might in principle subscribe to the Universal Declaration's equality of humans in dignity and rights. They tend, however, to be exclusionary and restrictive in their approach to moral situations.

- Taken together, the preceding suggests to Ignatieff that people still favor "us" over "them," preferring the claims of citizens to strangers'. Appeals to a common sense of generosity are likely to be effective in local, rather than global, settings. Acting on behalf of strangers is to "call forth the extraordinary virtues."

- The author argues further that the ordinary virtues unite us, but they can also divide us. On one hand, they are what "make[s] the multicultural experiment work" and are "the key to healing, reconciliation, and solidarity" worldwide. On the other, they are "easily exploited for a politics of fear and exclusion," as one's own group is privileged over others. ${ }^{12}$

- Ignatieff observes that, while different groups can live in the same societies, they do so apart rather than together; they prefer to associate with their own. He infers that self-segregation may be the most sustainable form of pluralism, not just in multiethnic New York City but also in conflict-riven Bosnia.

\footnotetext{
${ }^{5}$ About This Book, The Ordinary Virtues: Moral Order in a Divided World, Harvard UnIVERSITY Press, http://www.hup. harvard.edu/catalog.php?isbn=9780674976276 (last visited Apr. 30, 2019).

${ }^{6}$ IGNATIEFF, supra note 1 , at 28.

${ }^{7}$ Contrast this observation with that of Stuurman, who, looking at the longue durée, sees the emergence of a common humanity and a move toward human rights worldwide, driven by an evolution of ideas. SIEP STUURMAN, THE INVENTION of Humanity: Equality and Cultural Difference in World History (2017).

${ }^{8}$ IGNATIEFF, supra note 1 , at 26-27.

${ }^{9} I d$. at 206.

${ }^{10} \mathrm{Id}$. at 28 .

${ }^{11} I d$. at 213 (emphasis added).

${ }^{12}$ About This Book, supra note 5.
} 
- Ties of solidarity and the power of the ordinary virtues are described as fragile-" a precarious achievement"13 — and might succumb to ordinary vices of resentments, pettiness, and chauvinism. All it takes is a moment of "extraordinary vice" like violence to make us question the goodwill of our neighbors. ${ }^{14}$

- Most pointedly, Ignatieff concludes as regards our nature that " $[\mathrm{t}]$ he human rights revolution has changed what we believe about the duty of states. I doubt it has changed us." 15

\section{Methodological Critique}

The first difficulty that the report raises for me concerns the representativeness of its sampling, especially if, as Ignatieff claims, morality around the world is characterized by contextual singularity. The author - and a small team of researchers-recognized from the outset that the book project could not realistically be "completely global." ${ }^{16}$ In the event, they visited six countries for short periods of time. The six countries are, of course, far short of the roughly two hundred existing today, and they were selected based on local like-minded contacts or prior knowledge. Most interlocutors were-like the author and his team-experts and "themselves examples of globalization in action." 17 Ignatieff did also speak with monks in Myanmar, LA gang leaders, and dwellers of favelas in Rio de Janeiro-among other eclectic personalities-, and their stories seem well told. Yet to what extent are even these samples representative of the greater population in those half-dozen countries? In Ignatieff's report, the majority seems to be truly a silent one. ${ }^{18}$

The limits of the narrative journalism practiced are also evident elsewhere in The Ordinary Virtues, and they raise further concerns about Ignatieff s project. Whether Ignatieff and companions upheld recognized scientific standards in soliciting information about these people's valuesfor example, whether they framed their questions neutrally and whether their observation did not affect the way that the others behaved-is a big open question since the method followed is unclear. Moreover, his interpretation of the answers solicited is open to question. Ignatieff himself admits that his expert companion on the world tour returned to New York City with a view different from his about the number and interrelation of the virtues. ${ }^{19}$

\section{Implications of Findings}

Assuming for discussion's sake that Ignatieff's methodology is sound and that his findings are valid, what implications might this "intimate" report have for public policy, be it in terms of global ethics, international relations, and/or domestic politics?

I pose this question because it is immanent in the book, not because the author addresses it. In this regard, the project's purpose is equivocal. Ignatieff states at the outset that "[o]ur focus was not, in other words, on what people ought to have in common, but on what they actually do share when they face ethical pressure in their lives." ${ }^{20}$ What follows is indeed "richly descriptive." 21 Yet

\footnotetext{
${ }^{13}$ IGNATIEFF, supra note 1 , at 72 .

${ }^{14} I d$. at 29.

${ }^{15} I d$. at 216.

${ }^{16} I d$. at 3.

${ }^{17} I d$. at 4 .

${ }^{18}$ The meaningfulness of statements such as the following is questionable: "[E]veryone we talked to took it for granted that their voice counted for something . . . Everyone simply took it for granted that they had the right to engage with, disagree with, joke with us." The author and companions did not visit any places where sharia law or the caste system still rules. Id. at 198.

${ }^{19} I$ d. at 203 .

${ }^{20} I d$. at 25.

${ }^{21}$ Kieran Setiya, Common Sensibility: How Humanity Copes with Horror, Times Literary Supplement, Nov. 3, 2017 , at 15.
} 
few pages later he succumbs to the temptation concomitant with being a public intellectual who has just conducted a multi-year world tour: Ignatieff's purpose proves also to be prescriptive.

Should then ordinary virtues simply be acknowledged/taken note of; be maintained/confirmed; or even be developed/improved on, each by specific policies and institutions? Here again, Ignatieff shows mixed feelings: he cannot endorse the ordinary virtues that he identifies without significant qualifications. First, he is loath to pass judgment on the moral perspective of most people and prefers to show humility and tolerance. If these are self-determining people who know best how to live with diversity and who must accommodate other groups practically, it is incumbent upon others to be restrained in recommending policy. ${ }^{22}$ In earlier books, Ignatieff was committed to liberal freedom following his mentor, Isaiah Berlin, ${ }^{23}$ and he argued that rights are "a bare human minimum" internationally. ${ }^{24}$ In this book, Ignatieff notes that the ordinary virtues remain superior to the ordinary vices of "greed, lust, envy, and hatred" that Michel de Montaigne warned of centuries ago. ${ }^{25}$ Ignatieff vacillates further in describing this popular perspective as an understandable concern for family, friends, neighbors, and significant others, and as a denial or violation of the rights of strangers who remain human beneath any diversity. ${ }^{26}$ To choose a last example, Ignatieff advocates both democratic self-determination —"the first human right" 27 — and other rights of individual and collective equality. The former stands though in a Spannungsverhältnis-relationship of tension-with the latter. Self-determination may lead to the violation of equality by facilitating the expression of group loyalties and resentments: domestically, in a tyranny of the mass opinion regarding ethnic minorities; internationally, in chauvinism regarding other nations.

Ultimately, the author adopts a pragmatic stance regarding the prevailing situation. "A global ethic, applicable to all mankind, is essentially unimaginable and irrelevant," ${ }^{28}$ as it does not speak to people's quotidian struggles. It is too remote, too impersonal, to engage with the mundane choices that most must make. At the same time, Ignatieff sees persisting in prescribing universal human rights like latter-day moral activists as futile; the freedoms that exist in some societies cannot be extended tout court throughout the world. He deems such moral idealization as utopian and reconciles his liberal inclinations with his empirical findings, downscaling his political theory to fit the prosaic social practices. ${ }^{29}$

Rather than recommend a proactive program for positive change at home or abroad, Ignatieff seems essentially resigned to drawing attention to and reflecting the lived reality. ${ }^{30} \mathrm{He}$ restricts himself to discussing the conditions under which the ordinary virtues might "flourish" or "remain ordinary." He asks "[w] hat institutional conditions foster these [ordinary] virtues and in what political circumstances do they decay?" In answer, he writes hopefully, "good institutions" can encourage the ordinary virtues and an upward spiral of a society; they can, but are not always able to, prevent a downward spiral of the elite into viciousness and predation. ${ }^{31}$ Passions may

\footnotetext{
${ }^{22}$ Ignatieff accuses others of moral presumptuousness: "It is surprising that international human rights activists should take their own standing for granted . . . [T] he standing of the promoters of moral universalism was contested everywhere we went." IGNATIEFF, supra note 1, at 206, 207.

${ }^{23}$ See Michael Ignatieff, Isaiah Berlin: A Life (1998).

${ }^{24}$ Michael IgnatiefF, Human Rights as Politics And Idolatry 95 (2001).

${ }^{25}$ IgNATIEFF, supra note 1 , at 29.

${ }^{26}$ See also Paul Bloom, Against Empathy: The Case for Rational Compassion (2016) (arguing that empathy is not an unmitigated good: it can lead us to take morally questionable decisions).

${ }^{27}$ IGNATIEFF, supra note 1 , at 17.

${ }^{28} I d$. at 202.

${ }^{29}$ For more regarding the conceptual choice being made, see KWAME ANTHONY APPIAH, As IF: IDEALIZATION AND IDEALS 147-48 (2017).

${ }^{30}$ The failure of many other liberals to do likewise is arguably why anti-liberal movements are advancing. "Liberalism and empiricism have parted company, and nothing has been learnt." John Gray, Un-liberty: The Problem of Hyper-liberalism, Times Literary Supplement, Mar. 30, 2018, at 4.

${ }^{31}$ IgnatiefF, supra note 1 at 29-30. See alone the title of Saul Friedlaender, The Moral Collapse of the Elites. Nazi Germany AND the Jews: The Years of Persecution 1933-39 (1997).
} 
not only be channeled by public institutions; social practices are often contingent on faith in institutions-for example, that officials are not corrupt. Ignatieff s expectations are correspondingly modest: such state institutions cannot take humanity to heaven, but they might save it from hell, as the first Secretary-General said of the United Nations.

Some reviewers of The Ordinary Virtues have been less reticent than its author in pronouncing on morality internationally and in promoting democracy and rights. Indeed, these reviewers have been strident in making policy recommendations based on Ignatieff s findings: they see real potential in these findings for moral progress in domestic politics or international relations. Janice Stein of the University of Toronto argues that Ignatieff s reasoning, though based largely on dialogues in the developing world, can be easily extended to the developed world, in order to deal with the crisis perceived in liberal democracies today. Oxford's Adam Roberts states that the ordinary virtues described by Ignatieff offer a moral system that "actually works," as liberal and democratic principles are being widely challenged. ${ }^{32,33}$

What then is the appropriate response for readers, especially would-be moralizers among politicians, at universities and in NGOs, to the findings in The Ordinary Virtues about core values? What, in short, should be made of Ignatieffs insights? I believe that the implications for public policymaking are not as auspicious as Stein and others contend, in either developed or developing states. Stipulating the common qualities that influence disparate persons situated in radically different contexts will be, at a minimum, challenging.

The capacity of states to encourage the development of virtue is, on Ignatieff's own findings, limited. Liberal societies allow the ordinary virtues to flourish; they "create laws and institutions that make virtue ordinary." ${ }^{4}$ The idea that these virtues would flourish without official regulation is, according to Ignatieff, fantasy. Trust and reciprocity depend, at least, on supportive public institutions. The ordinary virtues are facilitated by the adequate maintenance of the rule of law-insofar as they already prevail in society. The ordinary virtues must be present in actual "citizens of virtue" who function as the social elite. They are additionally assumed to be inherent to individuals and by extension to groups. ${ }^{35}$ The state seems to be a catalyst for change and nothing more, as " $[\mathrm{g}]$ ood institutions can give courage to virtue and inspire an upward spiral toward repair and renewal." 36

Insofar as it goes, this argument is convincing. It does not, however, go far enough. A virtuous circle must begin with virtue. To my mind, the individual plays the decisive role in the process: as Cicero reputedly put it, the welfare of the society lies within the character of the citizen. What then if this character is not essentially good; or if citizens of virtue are not leading the society concerned; or if an interventionist politics is not supported popularly? It seems that in those contexts, a virtuous circle cannot be produced. To paraphrase the Christian apologist C.S. Lewis, you cannot make people good by law, but without good people you cannot have a good society. There is little use in alone prescribing that human beings be honest, kind, and helpful to one another-these very qualities are required to make any social and economic system work properly. ${ }^{37}$

To put this quandary in individual terms, it must be recalled that humans are creatures of habit. Humans do in principle have the power to change their habits through daily practice of new habits - here, that of living together peacefully with members of other groups. Their ordinary vices may be reformed into virtues, ordinary or even extraordinary. Nevertheless, one asks oneself, following the German philosopher Peter Sloterdijk, whether members of conflicting groups are in effect

\footnotetext{
${ }^{32}$ References are made to the demonstrated resilience of workers during the Fukushima nuclear plant meltdown and to the stubborn reassertion of community after the terrorist attacks in Paris in November 2015. IGNATIEFF, supra note 1 at $221,151$.

${ }^{33}$ Reviews, supra note 3.

${ }^{34}$ IGNATIEFF, supra note 1 at 195.

${ }^{35}$ It may be critically asked whether, as Ignatieff presumes, group morality should be considered synonymous with individual morality. Might not collective action such as mobbing diverge ethically?

${ }^{36}$ IGNATIEFF, supra note 1 at 30.

${ }^{37}$ C.S. LEWIS, A YeAR WITH C.S. LEWIS 70 (2003).
} 
trapped in a vicious circle: "Man tut nur, was man kann, und man kann nur, was man ständig wiederholt." 38

The next, no less important, corollary to be considered is how the norms can be agreed among the people concerned. How can a single code be established amid the diversity of philosophical, legal, and religious views and practices in the world, especially amid a prevailing attitude of individualism and respect for difference? Recourse to democracy and its decision-making mechanisms is no guarantee of progressive laws and institutions, as Ignatieff recognizes through a dismaying experience in South Africa recounted. Instead, it seems that the actual "citizens of virtue" must function as the social elite, for they enable societies to hang on to decency. This arrangement seems akin to Plato's famous argument for government by "the best." Whatever the wisdom in theory of meritocratic elites, the people-or rather voters in democracies-will not acquiesce in being so ruled; they consider politicians to be their representatives, heeding their sentiments, serving their needs, and meeting their demands. ${ }^{39}$

In the alternative, I wonder whether the pursuit of ordinary virtues, like the ideals of human rights, expect too much of people's virtues. Widespread belief in the universal equality of all human beings might be unrealistic, at present or in future. Likewise, might it be that the model of democratic government asks for unattainable effort on our collective part-for example, to inform oneself about political issues, to exercise rationality in deciding among policy options, or to participate actively in public deliberation? More objective historical reference suggests that the prospects for liberal democracy's realization are not good. For example, the German chronicler and human rights advocate Theodor Mommsen despaired already in 1894 about the power of man's destructive instincts and the powerlessness of morality and reason to restrain their expression: "Ich habe. .. immer wieder gegen die ungeheure Schmach protestiert, welche Antisemitismus heißt. Aber es nützt nichts. Es ist alles umsonst. .. . [D] as sind doch immer nur Gründe, logische und sittliche Argumente. Darauf hört doch kein Antisemit. Die hören nur auf den eigenen Haß und den eigenen Neid. ... Alles andere ist ihnen gleich." ${ }^{30}$ Pernicious ideas like antisemitism have proven to be awfully tenacious - and not only in Germany. Liberal hope and promise should be accordingly tempered by skepticism and experience of repeated disappointment.

\section{E. Conclusion}

These and further ${ }^{41,42}$ questions about moral globalization that The Ordinary Virtues: Moral Order in a Divided World raises are undoubtedly important and topical. When generalized, the book's findings urge us to reconsider the possibilities and potential of social ordering at home and abroad.

The consequences are not obvious to me. The Ordinary Virtues' methodology is muddled (is the book a personal reportage or a scientific study?); purpose equivocal (is its intention

\footnotetext{
${ }^{38}$ (Roughly translated as: one only does what one can, and one can only what one constantly repeats.) Uwe Justus Wenzel, Üben, üben, üben! Peter Sloterdijks kulturpsychologische Exkursionen ins unübersichtliche Gelände der "Anthropotechniken," Neue ZÜrCher Zeitung, Apr. 4, 2009.

${ }^{30} \mathrm{Kratsev}$ considers, for example, the Brexit referendum result to have been caused by "the inability and unwillingness of liberal elites to discuss migration and contend with its consequences." IVAN Krastev, After Europe 25 (2017).

${ }^{40}$ (Roughly translated as: I have protested time and time again against the monstrous disgrace that is antisemitism. But it has no effect. It's all for naught. ... Those are only reasons, logical and moral arguments. No antisemite listens to them. Antisemites listen only to their own hate and their own envy. ... They don't care about anything else.) HERmanN

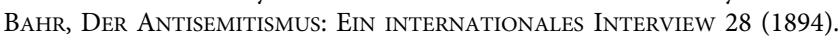

${ }^{41}$ As one reviewer has noted, ordinary virtue is itself limited, like the human rights discourse Ignatieff shows up: "Its remit is inherently conservative, resilience not transformation .... [Given foreseeable global challenges like climate change], [w]e will need more than ordinary virtue to see us through the next century without disaster." SETIYA, supra note 21.

${ }^{42}$ According to Ignatieff, fighting enemies of ordinary virtues such as terrorists can justify extreme measures. "Sometimes, violence cannot be resisted with argument: it must be met with force. . . Many moral conflicts will be settled with blood and fire." IGNATIEFF, supra note 1 at 222.
} 
description or prescription?); its conclusion ambivalent (apparently our moral conscience is dominated by neither human rights nor ordinary vices but by "ordinary virtues"); and its recommendations lacking conviction (Ignatieff defers to this conscience and concedes that morality, "in the deepest realms of our hearts," only changes slowly). ${ }^{43}$

At all events, the findings of Ignatieff s book cannot be reassuring for contemporary liberals and cosmopolitans like the reviewers cited above. The flourishing of human rights internationally that they advocate describes neither the contemporary reality nor the foreseeable future. Indeed, the well-ordered societies, in which the practices of the ordinary virtues have become deeply entrenched, seem difficult, if not impossible, to achieve in a divided world. What we admire morally and what is to be seen in society may diverge significantly and grievously. ${ }^{44}$

\footnotetext{
${ }^{43} I d$.

${ }^{44}$ Anderson argues that this perspective already existed in Victorian liberalism; in its philosophy and literature, the prospect of a "happy ending" is militated against by "sobering outlooks on sociological trends, psychological tendencies, and the political efficacy of argument and ideas." It is the progressive liberal optimism of the 20th century that constitutes a historical aberration in liberal thinking. Amanda ANDERSON, Bleak Liberalism 32 (2016).
} 